\title{
PENGARUH PERCEIVED QUALITY DAN BRAND IMAGE TERHADAP BRAND LOYALTY DAN BRAND EQUITY
}

\author{
Gusti Bagus Yopi Brangsinga ${ }^{1}$ \\ Tjok Gde Raka Sukawati ${ }^{2}$
}

\author{
${ }^{1,2}$ Fakultas Ekonomi dan Bisnis Universitas Udayana (Unud), Bali, Indonesia \\ E-mail:bagusyopi1993@gmail.com
}

\begin{abstract}
ABSTRAK
Tujuan dari penelitian ini adalah untuk mengetahui pengaruh perceived quality dan brand image terhadap brand loyalty dan brand equity. Penelitian ini berbentuk asosiatif dan dilakukan pada konsumen handphone Samsung Galaxy. Sampel dalam penelitian ini berjumlah 112 orang yang diambil dengan menggunakan teknik pengambilan sampel purposive sampling, yaitu teknik penentuan sampel dengan pertimbangan tertentu yang dianggap dapat mewakili populasi. Teknik analisis data dilakukan dengan menggunakan Structural Equation Modeling (SEM) dengan program AMOS 16.00.Hasil dari penelitian ini menunjukkan bahwa seluruh hipotesis diterima. Perceived quality dan brand image berpengaruh positif dan signifikan terhadap brand equity. Hal ini berarti perceived quality dan brand image yang baik akan membentuk brand equity yang baik pula bagi perusahaan. Perceived quality dan brand image berpengaruh positif dan signifikan terhadap brand loyalty. Saat perceived quality konsumen terhadap merek baik dan brand image yang dihasilkan baik pula maka akan terbentuk brand loyalty konsumen. Lalu brand loyalty berpengaruh positif dan signifikan terhadap brand equity. Dengan adanya brand loyalty konsumen hal tersebut akan menambah nilai positif yang dimiliki merek dan akan menambah brand equity merek maupun perusahaan.
\end{abstract}

Kata kunci: perceived quality, brand image, brand loyalty, brand equity

\begin{abstract}
The purpose of this study was to determine the effect of perceived quality and brand image on brand loyalty and brand equity. This research is in the form of associative and carried out on consumers of Samsung Galaxy mobile phones. The sample in this study amounted to 112 people taken using purposive sampling sampling technique, namely the technique of determining the sample with certain considerations that are considered to represent the population.. The results of this study indicate that all hypotheses are accepted. Perceived quality and brand image have a positive and significant effect on brand equity. This means that good perceived quality and brand image will form a good brand equity for the company. Perceived quality and brand image have a positive and significant effect on brand loyalty. When the perceived quality of consumers towards good brands and the resulting brand image is good, consumers will develop brand loyalty. Then brand loyalty has a positive and significant effect on brand equity. With the brand loyalty of consumers it will add to the positive value that the brand has and will add to the brand equity of the brand and company.
\end{abstract}

Keywords: perceived quality, brand image, brand loyalty, brand equity 


\section{PENDAHULUAN}

Arus globalisasi yang semakin pesat turut memicu terjadinya sebuah fenomena dimana teknologi seakan telah menjadi sebuah kebutuhan hidup. Fenomena ini menjadikan berubahnya cara masyarakat berinteraksi antar sesama dimana penyampaian informasi tidak lagi dilakukan dengan cara verbal. Komunikasi dapat dilakukan dengan memanfaatkan alat komunikasi yang telah memiliki teknologi untuk dapat mengirimkan dan menerima informasi secara cepat dan mudah. Saat ini setidaknya ada sekitar 7 miliar pengguna mobile di seluruh dunia. Sementara itu, jumlah pengguna layanan mobile selama ini tumbuh 7 persen tiap tahunnya. Saat ini memang banyak pengguna mobile yang memiliki lebih dari satu perangkat, termasuk di Indonesia. Mereka biasanya menggunakan gadget yang berbeda untuk keperluan pekerjaan atau pertemanan. (tekno.kompas.com). Teknologi smartphone yang selalu berkembang menyebabkan konsumen selalu ingin mengupdate smartphonenya, maka kebanyakan kaum remaja selalumembeli lagi smartphoneversi terbaru dengan berbagai alasan seperti kebutuhan sekolah bahkan hanya untuk mendapatkan prestise yang tinggi (Ahmed et al.,2011).

Teknologi yang terus berkembang dan canggih menjadikan masyarakat dapat dengan mudah melakukan kegiatannya dalam berbagai hal. Mengirim pesan, membayar tagihan, mencari berita atau informasi bahkan menonton film dapat dilakukan melalui layar handphone yang dimiliki. Kondisi tersebut menjadikan para produsen handphone berlomba untuk menghadirkan produk dengan teknologi yang semakin canggih guna mendapatkan perhatian masyarakat 
hingga akhirnya perusahaan tersebut memiliki posisi yang kuat dalam masyarakat. Menurut Kotler \& Armstrong, (2001: 346) produk adalah segala sesuatu yang dapat ditawarkan kepasar untuk mendapatkan perhatian, dibeli, digunakan, atau dikonsumsi yang dapat memuaskan keinginan atau kebutuhan. Selain itu produk dapat pula didefinisikan sebagai persepsi konsumen yang dijabarkan oleh produsen melalui hasil produksinya. Produk dipandang penting oleh konsumen dan dijadikan dasar pengambilan keputusan pembelian.Jika pelanggan tidak tertarik pada suatu merek dan membeli karena karateristik produk, harga, kenyamanan, dan dengan hanya sedikit memperdulikan merek, kemungkinan ekuitas mereknya rendah. Sedangkan jika para pelanggan cenderung membeli suatu merek walaupun dihadapkan pada para pesaing yang menawarkan produk yang lebih unggul, misalnya dalam hal harga dan kepraktisan, maka merek tersebut memiliki nilai ekuitas yang tinggi (Rangkuti, 2002).

Terdapat berbagai merek produk handphone yang ada di industri smartphone saat ini, beberapa diantaranya merupakan merek yang tidak asing lagi di telinga kita sepertiIphone, Samsung, Blackberry dan Nokia. Selain itu, terdapat beberapa merek lain yang ikut meramaikan persaingan dan mencoba mendapatkan posisi didalam masyarakat antara lain Oppo, Huawei Vivo dan Advan yang merupakan merek handphone dari Indonesia.Indonesia tidak diragukan lagi salah satu pasar yang paling menarik di Asia Tenggara dengan populasi lebih dari 250 juta jiwa terbesar di wilayah Asia Tenggara dan keempat terbesar di dunia, setelah Cina, India dan Amerika Serikat menjadikan Indonesia sebagai pasar yang potensial. Indonesia saat ini memiliki 88,1 juta pengguna internet aktif, naik 15 
persen selama 12 bulan. Pasar ponsel telah meledak selama beberapa tahun. Langganan SIM di Indonesia berdiri pada 326.3 juta, jauh melebihijumlah penduduknya. Ini berarti setiap pengguna ponsel memiliki rata-rata dua kartu SIM. 85 persen dari penduduk Indonesia memiliki ponsel,sementara43persen diantaranya membawa smartphone(techinasia.com). Salah satu perusahaan yang melirik pasar smartphone Indonesia adalah Samsung dengan merek smartphone Samsung Galaxy yang banyak diminati oleh penduduk Indonesia.

Samsung didirikan oleh Lee Byung Chull pada tanggal 1 maret 1938 di Daegu, Korea Selatan. Saat ini kejayaan Samsung tidak diragukan lagi. Perusahaan asal Korea Selatan itu berkembang menjadi konglomerasi usaha dengan memproduksi berbagai produk mulai dari mesin pencuci piring hingga smartphone, sehingga menjadikannya sebagai salah satu brand paling kuat dan terkenal dalam dunia teknologi. Bahkan, kesuksesan Samsung tak kalah dengan raksasa teknologi lain dari Barat yaitu Apple, Facebook, Microsoft, dan Google, sebagai salah satu perusahaan teknologi paling penting saat ini. Kisah yang paling menarik dimulai pada Maret 2010 ketika Samsung memperkenalkan Galaxy S, ponsel andalan pertama perusahaan itu. Saat itu, Galaxy S secara luas dianggap sebagai salah satu alternatif terbaik untuk iPhone 3GS. Menurut keterangan Samsung, Galaxy S berhasil terjual 10 juta unit pada tahun pertama meluncur (techno.okezone.com).

Pada tahun 2011 Samsung mengeluarkan smartphone terbaru yaitu Galaxy S II yang saat itu menjadi smarphone andalan dari Samsung. Ponsel itu memilii performa yang lebih baik dibanding pendahulunya, serta memiliki tampilan lebih 
besar dan prosesor lebih cepat. Saat itu, banyak yang menganggap Galaxy S II sebagai salah satu ponsel terbaik Android. Samsung meluncurkan kategori produk baru pada Oktober 2011 yaitu Galaxy Note. Perangkat tersebut termasuk dalam kategori phablet yakni persilangan antara smartphone dan tablet. Note memiliki layar 5,3 inci dan dilengkapi stylus untuk menggambar dan mencatat. Meskipun awalnya mendapat perhatian kritikus karena ukurannaya yang terlalu besar, tapi Samsung berhasil menjual sekira 10 juta unit Galaxy Note. Alhasil, penjualan tersebut sekaligus membuktikan ada permintaan dari kosumen terhadap ponsel dengan ukuran layar besar.

Samsung bukan satu-satunya produsen perangkat mobile dengan kualitas yang baik, perusahaan perangkat Andorid lainnya seperti HTC, LG, dan Motorola, juga memiliki produk yang tak kalah baik. Samsung memerlukan cara untuk membedakan pasukan Galaxynya dari rangkaian perangkat Android lain dan membuktikan bahwa ponsel tersebut bisa menjadi alternatif untuk iPhone yang menjadi saingan utama. Untuk itu, Samsung pun menyiapkan pundi-pundi yang tak sedikit dan memulai kampanye pemasaran yang agresif dan mahal. Samsung juga mulai dikenal dunia melalui smartphonenya yang sangat canggih dengan menggunakan OS Android ciptaan google, perusahaan ini sukses mengalahkan perusahaan lain seperti Blackberry dan Apple.

Kecanggihan teknologi yang dimiliki oleh Samsung Galaxy, menjadikan masyarakat di Indonesia semakin memilihsmartphone ini untuk keperluan komunikasinya. Menurut data IDC, Samsung telah melejit menjadi produsen smartphone terbesar di dunia dengan angka pengapalan produk mencapai 79,2 
juta unit pada kuartal pertama tahun 2017 jauh di atas para pesaing lainnya seperti Apple, Huawei, Oppo, Vivo dan yang lainnya.Walaupun permintaan pasar terhadap produk smartphone Samsung Galaxy saat ini mengalami peningkatan, tetapi tetap saja Samsung Galaxy masih mempunyai pesaing dari berbagai merek smartphone lainnya. Belum lagi,handphone-handphone dari Cina yang dianggap bersaing dengan harga yang rendah tapi mempunyai keunggulan yang hampir sama dengan Samsung Galaxy.

Untuk tetap mempertahankan pangsa pasar yang positif di Indonesia, perusahaan Samsung dengan Samsung Galaxy terus berupaya menciptakan produk baru dengan menciptakan berbagai tipe produk dengan inovasi baru dan promosi yang aktif dengan menggunakan berbagai media promosi untuk memperkenalkan produknya pada masyarakat secara lebih luas lagi. Oleh karena itu, penulis melakukan penelitian pendahuluan yang dilakukanterhadap 15 orang responden konsumen handphone Samsung Galaxy.

Tabel 1. Penelitian Pendahuluan

\begin{tabular}{llc}
\hline \multicolumn{2}{c}{ Pernyataan } & \multicolumn{2}{c}{ Jawaban Responden } \\
& Ya & Tidak \\
\hline Pernah atau sedang menggunakan handphone Samsung & 13 & 2 \\
Selalu mengikuti perkembangan handphone terbaru & 10 & 5 \\
Samsung & 12 & 3 \\
Tetap memilih Samsung dari pada merek handphone lain & &
\end{tabular}

Hasilnya mayoritas responden menggunakan handphone Samsung Galaxy dan beberapa diantaranya berpindah ke smartphone Android lainnya. Dari 15 responden 10 responden selalu mengikuti perkembangan informasi mengenai handphone Samsung mulai dari informasi mengenai teknologi yang ada di handphone Samsung sampai dengan informasi keluaran produk terbaru melalui 
forum-forum diskusi yang tersedia. Sebanyak 11 dari 15 responden menjawab bahwa tetap memilih handphone Samsung Galaxy dari pada merek handphone lainnya. Dari hasil penelitian pendahuluan yang dilakukan oleh penulis, merek memiliki peranan penting di dalam pasar karena merek menjadi sebuah pembeda antara produk satu dan yang lainnya diantara komoditas yang ada. Merek adalah nama, istilah, tanda, simbol, rancangan, atau kombinasi dari hal-hal tersebut, yang dimaksudkan untuk mengidentifikasikan barang atau jasa dari seorang atau sekelompok penjualdan untuk membedakannya dengan produk pesaing (Philip Kotler, 2005:460). Menurut data yang dikeluarkan oleh International Data Corporation (IDC)mengungkapkan beberapa statistik menarik pada laporan terbarunya. Pada triwuan pertama 2017, total perangkat smartphone yang dikapalkan mencapai 347,4 juta unit di seluruh dunia. Angka ini juga berarti ada peningkatan 4,3\% dari 332,2 juta unit yang dikirim pada periode yang sama tahun lalu.

Dari hasil survey yang dilakukan oleh IDC dapat dilihat bahwa Samsung pada kuartal 12017 ini masih menempati posisi pertama untuk market share global dengan jumah 22,80\% disusul oleh Apple diposisi kedua dengan 14,90\% dan Huawei diposisi ketiga dengan jumah 9,80\% selanjutnya diposisi keempat diduduki oleh Oppo dan Vivo di posisi paling akhir. Pada data tersebut dapat dilihat para pesaing Samsung mengalami peningkatan market share mereka di kuartal 1 tahun 2017 ini, namun untuk Samsung sendiri pada kuartal 1 tahun 2017 tidak mengalami peningkatan market share. Hal tersebut bisa dikarenakan oleh 
kejadian meledaknya handphone Samsung Galaxy Note 7 yang disebabkan tidak bekerja dengan baiknya sistem baterai mereka pada Agustus 2016.

Data Korea Insight Institute menunjukkan, persepsi negatif atas Galaxy Note 7 naik menjadi 53 persen pada Oktober, angka itu naik dari angka 34 persen pada Agustus lalu saat perangkat andalan itu pertama kali diperkenalkan. Berbanding terbalik persepsi positif atas Galaxy Note 7 turun menjadi 42 persen dari angka 62 persen pada periode yang sama. Adanya masalah ini menjadikan Samsung menghentikan produksi, distribusi dan menarik seluruh perangkat handphone Galaxy Note 7 di seluruh dunia. Samsung mengakui ada ketidakcermatan dalam mengontrol kualitas produk kelas premiumnya itu sehingga membuat perusahaan rugi materi dan reputasi nama besar Samsung jadi taruhannya (reuters.com). Keputusan itu meningkatkan kekhawatiran atas kualitas kendali dari produk Samsung. Selain itu momen buruk ini diperkirakan bakal berdampak pada reputasi Samsung. Sebab, bisa saja raihan penjualan produk Samsung direbut oleh Apple melalui iPhone 7 dan Google yang baru saja meluncurkan Pixel (viva.co.id).

Lee et al. (2010) mencatat bahwa ketika konsumen melihat merek yang berkualitas tinggi, mereka lebih cenderung untuk membeli merek tersebut daripada merek pesaing, membayar harga premium dan memilih merek. Persepsi kualitas dan nilai yang dirasakan memainkan peran penting dalam industri dengan keterlibatan pelanggan yang tinggi.Permasalahan yang dihadapi Samsung Galaxy Note 7 tentu akan mempengaruhi persepsi konsumen akan kualitas Samsung akan semakin dipertanyakan.Hal tersebut akan berhimbas pada citra Samsung dalam 
pemikiran konsumen. Setiadi (2003) berpendapat bahwa citra merek mengacu pada skemamemori akan sebuah merek, yang berisikan interpretasi konsumen atas atribut,kelebihan, penggunaan, situasi, para pengguna, dan karakteristik pemasardan/atau karakteristik pembuat dari produk atau merek tersebut. Citra merek adalahapa yang konsumen pikirkan dan rasakan ketika mendengar atau melihat namasuatu merek.

Ekuitas merek adalah seperangkat aset dan liabilitas merek yang berkaitan dengan suatu merek, nama, simbol, yang dapat menambah atau mengurangi nilai yang diberikan oleh sebuah produk atau jasa kepada perusahaan atau pelanggan perusahaan (Aaker, 1997).Kotler \&Keller juga menyatakan ekuitas merek adalah keinginan seseorang untuk melanjutkan menggunakan suatu brand atau tidak.Pengukuran dari ekuitas merek sangatlah berhubungan kuat dengan kesetiaan dan bagian pengukuran pengguna baru menjadi pengguna yang setia.Erfan Severi \& Kwek Choon Ling (2013) menyatakan pemasar harus memprioritaskan konstruksi ekuitas merek sebagai strategi mereka untuk menarik pelanggan potensial karena hal ini menunjukkan hubungan langsung dan tidak langsung yang signifikan antara dimensi ekuitas merek dan ekuitas merek.

Dalam penelitian ini menggunakan 2 elemen dari ekuitas merek yaitu persepsi kualitas (perceived quality) dan loyalitas merek (brand loyalty) ditambah dengan citra merek (brand image) dengan tujuan dapat mengetahui bagaimakah ekuitas merek sebuah produk dari perspektif pelanggan bisa tercapai.Berbicara mengenai ekuitas merek handphone Samsung Galaxy yang dilihat dari hasil penelitian pendahuluan penulis, maka dapat dikatakan bahwa handphone 
Samsung Galaxy mempunyai ekuitas merek yang tinggi dengan kecilnya angka perpindahan responden ke handphone lain dan tetap memilih handphone Samsung Galaxy walau produk pesaing memberikan kualitas dan teknologi yang tidak jauh berbeda dari Samsung Galaxy. Ini menunjukkan bahwa persepsi kualitas yang diharapkan konsumen dapat dipenuhi oleh handphone Samsung Galaxy sehingga menjadikan konsumen tetap memilih Samsung Galaxy sebagai alat komunikasi mereka.

Keputusan responden untuk tetap memilih handphone Samsung Galaxy ini didasarkan atas keyakinan responden pada merek sehingga timbul rasa percaya diri atas pilihan yang diambil. Rasa percaya diri yang dimiliki responden menandakan bahwa citra merek yang Samsung Galaxy berikan telah menjadikan konsumen percaya atas keseluruhan kinerja dari Samsung Galaxy. Citra baik tersebut akan menjadikan konsumen menjadi loyal terhadap Samsung Galaxy. Endang Tjahjaningsih dan Maurine Yuliani (2009) dalam penelitiannya menyatakan citra merekyang sudah cukup baik dimata konsumen atau masyarakat harus dijaga agar konsumen tetap loyal terhadap merek.

Kualitas adalah aspek penting yang harus dipertimbangkan untuk meningkatkan ekuitas merek. Perusahaan harus memastikan kualitas terbaik untuk merek mereka untuk menciptakan ekuitas merek. Persepsi kualitas tinggi memungkinkan konsumen untuk mengenali diferensiasi dan keunggulan merek, serta untuk memilih merek (Karupannan et al.,2012). Penelitian yang dilakukan pada layanan internet banking bank di Portugal menyatakan bahwa perceived 
quality memiliki pengaruh yang positif terhadap brand equity (Sandra Maria, 2013).

Mahsa Pishdar et al. (2014) menyatakan bahwa perceived quality memiliki pengaruh langsung terhadap brand equity.Hal ini diperkuat juga oleh hasil penelitian dari Adi Putra (2012) dan Ravi Shekhar et al. (2013) yang menyebutkan bahwa persepsi kualitas memiliki hubungan yang positif terhadap ekuitas merek.

$\mathrm{H}_{1}$ : Perceived quality berpengaruh secara positif dan signifikan terhadapbrand equity.

Penelitian yang dilakukan pada iklan telekomunikasi di Pakistan menunjukkan bahwa citra merekmerupakan penentu utama dari ekuitas merek. Citra merek menangkap fitur simbolis ekuitas merek,untuk itu pengiklan telekomunikasi harus mempertimbangkan karakteristik kepribadian merek mereka dari sudut konsumen pandang dan sehingga untuk mengembangkan citra merek menurut yang ideal konsep diri konsumen (Muhammad Qasimet al.2017).

Penelitian yang dilakukan oleh Jumiati Sasmita dan Norazah Mohd Suki (2014) menunjukkan bahwa variabel brand image berpengaruh positif terhadap brand equity. Ketika produk tersebut memiliki brand image yang positif, konsumensadar bahwa produk atau merek tersebut memiliki keunikan dibandingkan dengan produk atau merek lain.Fiola Asti Imarta (2013) dalam penelitiannya pada KFC Veteran Padang juga mendapatkan hasil bahwa citra merek memiliki hubungan yang positif dan signifikan terhadap ekuitas merek. Penelitian yang dilakukan pada perokok usia muda di Semarang juga menunjukan 
hasil bahwa brand image berpengaruh secara positif terhadap brand equity (Ryan Anggra, 2014).

$\mathrm{H}_{2}$ : Brand image berpengaruh secara positif dan signifikan terhadapbrand equity.

Di pasar saat ini, kesuksesan sebuah merek memerlukan ikatan yang kuat dengan konsumen, dengan menciptakan hubungan yang baik, kuat dan asosiasi merek yang unik di benak konsumen. Penelitian yang dilakukan oleh Irem et al.(2012) bertujuan untuk mengidentifikasi peran fungsional (persepsi kualitas) dan asosiasi merek simbolik (kepribadian keselarasan dan prestise merek) dalam menciptakan loyalitas merek di sektor ready-to-wear dari perspektif Generasi Y konsumen Turki. Hasilnya adalah hanya persepsi kualitas yang memiliki efek langsung pada sikap merek dan loyalitas merek.

Hasil penelitian Hong et al. (2012) pada department store China juga menunjukkan bahwa persepsi kualitas berhubungan positif dengan loyalitas merek. Ini adalah tes dari efek utama pada loyalitas merek. Fanny dan Diah (2014) dalam penelitiannya terhadap pelanggan mobil Toyota di Surabaya menyebutkan bahwa persepsi kualitas berpengaruh signifikan terhadap loyalitas merek.Perceived quality mobil Toyota dinilai paling tinggi dalam hal serviceability yaitu dapat membuat jadwal (making appointment) dengan dealer Toyota, sehingga tidak perlu antri jika melakukan servis.

$\mathrm{H}_{3}$ : Perceived quality berpengaruh secara positif dan signifikan terhadap brand loyalty.

Penelitian yang dilakukan Muhammad Rizan dkk (2012) pada konsumen

Teh Botol Sosro di Food Court ITC Cempaka Mas, Jakarta timur menyatakanbahwa citra merek memiliki pengaruh yang positif dan signifikan 
terhadap loyalitas merek Teh Botol Sosro. Penelitian yang dilakukan pada pasar ponsel di Suriah dengan target mahasiswa dari universitas lokal menyatakan bahwa antara brand image dan brand loyalty memiliki pengaruh yang positif dan signifikan (Abdullah, 2015). Penelitian pada konsumen air minum Ades di Surabaya menunjukkan variabel brand image berpengaruh positif signifikan terhadap brand loyalty. Hal ini menunjukkan citra merek yang dibentuk karena perusahaan mampu memberikan presepsi yang baik kepada konsumennya dan juga menjaga dan mengelola hubungan dengan konsumen (Danny Alexander, 2014).

Penelitian yang dilakukan pada sektor telekomunikasi nirkabel Pakistan menyatakan bahwa brand image memiliki pengaruh positif dan signifikan terhadap brand loyalty.Dengan mengacu pada kepuasan dan loyalitas, penting bagi perusahaan untuk menentukan kepuasan pelanggan dalam rangka untuk memeriksa produk atau layanan gambar mereka, kinerja dan apakah pelanggan yang puas mereka bersedia untuk menyarankan produk mereka kepada orang lain selain memiliki maksud untuk pembelian produk atau layanan di masa depan (Rashid et al. 2013). Namun hasil yang berbeda didapat pada penelitian Aisya (2013) yang menyatakan bahwa brand image tidak berpengaruh secara positif terhadap brand loyalty pada pengguna jasa RS. PKU Muhammadiyah Surakarta. $\mathrm{H}_{4}$ : Brand image berpengaruh secara positif dan signifikan terhadapbrand loyalty. Hossien et al. (2012) menyatakan dalam penelitiannya pada konsumen cokelat di Iran bahwa brand loyalty memiliki pengaruh yang sangat besar terhadap brand equity. Ini berarti bahwa perusahaan harus menempatkan penekanan lebih besar dalam menciptakan loyalitas merek untuk produk mereka. 
Untuk memastikan pelanggan setia, produsen dan pengecer perlu membangun hubungan jangka panjang dengan pelanggan mereka, menawarkan dan mempertahankan produk berkualitas tinggi, dan memberikan pelayanan yang baik.

Shen Lei \&Luo Chu (2015) dalam penelitiannya pada beberapa merek olahraga di China menyatakan hubungan yang positif dan signifikan antara brand loyalty terhadap brand equity. Penelitian yang dilakukan pada pembeli potensial Walmart di Amerika Serikat mendapatkan hasil bahwa brand loyalty memiliki hubungan yang positif dan signifikan terhadap brand equity (Tulay et al. 2017).

Bisfidayani menyatakan loyalitas tinggi yang dimiliki konsumen terhadap suatu produk juga akan berdampak pada meningkatnya ekuitas merek. Faktor loyalitas yang berdampak pada ekuitas merek dapat terlihat apabila konsumen tidak mau berpindah ke merek lain dan tetap memilih merek tersebut saat ingin membeli kembali. Anis (2010) menyatakan brand loyalty memiliki dampak yang positif terhadap brand equity pada produk deodorant Rexona dan didukung juga oleh penelitian Selly (2012) menyatakan bahwa secara statistik dapat ditunjukkan brand loyalty memiliki pengaruh yang positif terhadap brand equity pada pasta gigi Pepsodent.

$\mathrm{H}_{5}$ : Brand loyalty berpengaruh secara positif dan signifikan terhadapbrand equity.

\section{METODE PENELITIAN}

Penelitian ini mengambil tempat di kota Denpasar. Hal ini dikarenakan pertumbuhan dan perkembangan pertokoan yang menyediakan handphone dengan berbagai merek sangat pesat di kota Denpasar.Banyaknya toko handphonedengan 
bangunan besar dan merek yang lengkap di Jalan Teuku Umar menjadikan daerah tersebut menjadi pasar terbesar bagi produk handphone yang menjadikan konsumen akan menuju daerah tersebut untuk mendapatkan handphone yang dicarinya. Diperkuat oleh survey yang dilakukan oleh Sloka Institute bahwa kota Denpasar adalah pengguna internet/gadget terbesar di Bali, yaitu sebesar 54,2 persen diikuti oleh Kabupaten Badung 15,7 persen, Kabupaten Tabanan 7,1 persen, dan Kabupaten Gianyar 6,8 persen (sloka.or.id).

Dalam penelitian ini, populasi penelitian mengacu pada konsumen telepon seluler merek Samsung Galaxy di kota Denpasar.Karena populasi dalam penelitian ini yaitu orang yang merupakan konsumen telepon seluler merek Samsung Galaxy di Denpasar jumlahnya sangat banyak (tersebar dan sulit diketahui secara pasti), maka dilakukan pengambilan sampel untuk penelitian ini.Metode penentuan sampel yang digunakan dalam penelitian ini yaitu nonprobability sampling yaitu teknik pengambilan sampel yang tidak memberi peluang atau kesempatan yang sama bagi setiap unsur atau anggota populasi yang dipilih menjadi sampel (Rahyuda dkk., 2004).

Teknik non-probability sampling yang dipilih adalah purposivesampling yaitu teknik penentuan sampel dengan pertimbangan tertentu.Metode pengumpulan data yang digunakan dalam penelitian ini adalah dengan menggunakan kuesioner.Teknik analisis data yang digunakan dalam penelitian ini adalah Structural Equation Modeling (SEM).

\section{HASIL DAN PEMBAHASAN}

Tabel 2.

Nilai Construct Reliability dan Variance Extract 


\begin{tabular}{lccc}
\hline \multicolumn{1}{c}{ Konstruk } & $\begin{array}{c}\text { Construct } \\
\text { Reliability }\end{array}$ & Variance Extract & Keterangan \\
\hline Perceived Quality & 0,89 & 0,66 & Diterima \\
Brand Image & 0,81 & 0,52 & Diterima \\
Brand Loyalty & 0,85 & 0,58 & Diterima \\
Brand Equity & 0,90 & 0,70 & Diterima \\
\hline
\end{tabular}

Sumber:Data diolah, 2018

Berdasarkan tabel 2 seluruh nilai construct reliability dan variance extract masing-masing konstruk pada penelitian ini telah memenuhi batas-batas nilai yang disyaratkan, yaitu $\geq 0,70$ untuk construct reliability dan $\geq 0,50$ untuk variance extract. Hal ini berarti indikator-indikator yang digunakan dalam penelitian ini mempunyai konsistensi dan dapatmewakili dengan baik konstruk laten yang dikembangkan, yaitu perceived quality, brand image, brand loyalty, dan brand equity.

Dari hasil ujimodel pengukuran secara keseluruhan,menunjukkan bahwa model dan teori yang dikembangkan dalam penelitian ini selain cocok dengan data, juga mempunyai sifat bahwa setiap parameter atau indikatornya dapat menjelaskan kontruk yang diteliti dengan baik.

Berdasarkan hasil analisis persamaan struktural, maka diperoleh nilai kausalitas antar konstruk untuk menjawab hipotesis yang diajukan dalam penelitian ini. Untuk mempermudah melihat kekuatan pengaruh antar konstruk, baik pengaruh langsung, tidak langsung, maupun pengaruh totalnya, maka dapat dilihat pada diagram alur dari hasil analisis persamaan struktural.

Tabel 3.

\begin{tabular}{lllcc}
\hline Konstruk & Goodness of Fit & Nilai Kritis & $\begin{array}{c}\text { Nilai } \\
\text { Model }\end{array}$ & Keterangan \\
\hline Total & Probability & $\geq 0,05$ & 0,500 & Baik \\
& Chi-square & $\begin{array}{l}\text { Diharapkan Kecil } \\
(\leq 133,476)^{*}\end{array}$ & 97,324 & Baik \\
& CMIN/DF & $\leq 2,00$ & 0,993 & Baik
\end{tabular}




\begin{tabular}{lccc} 
GFI & $\geq 0,90$ & 0,899 & Marginal Fit \\
TLI & $\geq 0,95$ & 1,001 & Baik \\
CFI & $\geq 0,94$ & 1,000 & Baik \\
RMSEA & $\leq 0,08$ & 0,000 & Baik \\
AGFI & $\geq 0,90$ & 0,860 & Marginal Fit \\
\hline
\end{tabular}

Sumber:Data diolah, 2018

\section{Indeks Goodness of Fit}

Berdasarkan Tabel 3 hasil uji kesesuaian model secara keseluruhan (multivariate) telah menunjukkan bahwa semua kriteria goodness of fit terpenuhi setelah dibandingkan dengan nilai kritisnya. Hal ini menunjukkan bahwa model konstruk penelitian yang dibangun sesuai dengan teori yang dikembangkan.

Pada Tabel 4 terdapat nilai estimate antar konstruk sehingga diperoleh persamaan struktural sebagai berikut.

Tabel 4.

Nilai Estimasi Parameter

\begin{tabular}{cc}
\hline & Estimate \\
\hline $\mathrm{Y} 2 \leftarrow \mathrm{X} 1$ & 0,310 \\
$\mathrm{Y} 2 \leftarrow \mathrm{X} 2$ & 0,282 \\
$\mathrm{Y} 1 \leftarrow \mathrm{X} 1$ & 0,382 \\
$\mathrm{Y} 1 \leftarrow \mathrm{X} 2$ & 0,553 \\
$\mathrm{Y} 2 \leftarrow \mathrm{Y} 1$ & 0,395 \\
\hline
\end{tabular}

Sumber: Data diolah, 2018

Y2 $($ Brand Equity $)=0,310 X 1$. Pengaruh perceived quality terhadap brand equity bernilai positif. Hal ini menyatakan bahwa semakin baik persepsi konsumen terhadap kualitas serta keunggulan yang diberikan Samsung kepada konsumen dan sesuai dengan apa yang diharapkan, maka semakin baik pula nilai merek dari produk handphone Samsung Galaxy dalam pasar.

Y2 $($ Brand Equity $)=0,282 \mathrm{X} 2$. Pengaruh brand image terhadap brand equity bernilaipositif. Hal ini menyatakan bahwa semakin baik citra yang dimiliki Samsung dengan handphone yang dikeluarkan, maka semakin baik pula nilai merek dari produk handphone Samsung Galaxy dalam pasar. 
Y1 $($ Brand Loyalty $)=0,382 X 1$. Pengaruh perceived quality terhadap brand loyalty bernilai positif. Hal ini menyatakan bahwa semakin baik persepsi konsumen terhadap kualitas serta keunggulan yang diberikan Samsung kepada konsumen dan sesuai dengan apa yang diharapkan, maka konsumen akan semakin loyal terhadap produk handphone Samsung Galaxy.

Y1 $($ Brand Loyalty $)=0,553 \mathrm{X} 2$. Pengaruh brand image terhadap brand loyalty bernilaipositif. Hal ini menyatakan bahwa semakin baik citra yang dimiliki Samsung dengan handphone yang dikeluarkan, maka konsumen akan semakin loyal terhadap produk handphone Samsung Galaxy.

Y2 $($ Brand Equity $)=0,395 \mathrm{Y} 1$. Pengaruh brand loyalty terhadap brand equity bernilai positif. Hal ini menyatakan bahwa semakin tinggi loyalitas konsumen terhadap merek handphone Samsung Galaxy, maka semakin tinggi pula nilai merek yang dimiliki produk handphone Samsung Galaxy.

Analisis direct effect, indirect effect, dan total effect digunakan untuk melihat kekuatan pengaruh antar konstruk, baik pengaruh secara langsung, tidak langsung, maupun pengaruh totalnya.

Tabel 5.

Nilai Standardized Direct, Indirect, dan Total Effect

\begin{tabular}{cccc}
\hline & Direct Effect & Indirect Effect & Total Effect \\
\hline Perceived Quality $\rightarrow$ Brand Equity & 0,310 & 0,151 & 0,461 \\
Brand Image $\rightarrow$ Brand Equity & 0,282 & 0,218 & 0,5 \\
Perceived Quality $\rightarrow$ Brand Loyalty & 0,382 & - & 0,382 \\
Brand Image $\rightarrow$ Brand Loyalty & 0,553 & - & 0,553 \\
Brand Loyalty $\rightarrow$ Brand Equity & 0,395 & - & 0,395 \\
\hline
\end{tabular}

Sumber: Data diolah, 2018

Berdasarkan Tabel 5 terlihat bahwa variabel perceived quality memiliki pengaruh secara langsung terhadap variabel brand equity tanpa melalui brand 
loyalty sebesar 31 persen dan variabel brand image memiliki pengaruh secara langsung terhadap variabel brand equity tanpa melalui brand loyalty sebesar 28,2 persen. Variabel perceived quality memiliki pengaruh secara langsung terhadap variabel brand loyalty sebesar 38,2 persen, variabel brand image memiliki pengaruh secara langsung terhadap variabel brand loyalty sebesar 55,3 persen, variabel brand loyalty memiliki pengaruh secara langsung terhadap variabel brand equity sebesar 39,5 persen,

Selain pengaruh langsung, terdapat pengaruh tidak langsung antara variabel perceived quality terhadap variabel brand equity yang diperantarai oleh variabel brand loyalty dan variabel brand image terhadap variabel brand equity yang diperantarai juga oleh variabel brand loyalty. Variabel perceived quality memiliki pengaruh tidak langsung terhadap variabel brand equity melalui variabel brand loyalty sebesar 15,1 persen. Lalu variabel brand image memiliki pengaruh tidak langsung terhadap variabel brand equity melalui variabel brand loyalty sebesar 21,8 persen. Hal ini menunjukkan bahwa pengaruh variabel perceived quality maupun brand image terhadap variabel brand equity akan meningkat apabila diperantarai oleh variabel brand loyalty. Dalam penelitian yang dilakukan olehHardeep Chahal dan Madhu Bala (2010) menyatakan bahwa Secara khusus, hasil penelitian menunjukkan bahwa persepsi kualitas dan loyalitas merek memiliki pengaruh positif pada ekuitas merek dan secara keseluruhan, studi ini menyimpulkan bahwa loyalitas merek dan kualitas yang dirasakan adalah dua komponen yang berkontribusi pada pengembangan ekuitas merek.

Hasil pengujian hipotesis penelitian dapat dilihat pada Tabel 5 berikut: 
Tabel 6.

Nilai Estimasi Parameter Total handphone Samsung Galaxy di Kota Denpasar

\begin{tabular}{cccl}
\hline \multicolumn{1}{c}{ Direct Effect } & $\begin{array}{c}\text { Estimate } \\
\text { Standardized }\end{array}$ & p-value & Ket \\
\hline $\begin{array}{c}\text { Perceived Quality } \rightarrow \text { Brand Equity } \\
\text { Brand Image } \rightarrow \text { Brand Equity }\end{array}$ & 0,333 & 0,002 & Signifikan \\
Perceived Quality $\rightarrow$ Brand Loyalty & 0,363 & 0,026 & Signifikan \\
Brand Image $\rightarrow$ Brand Loyalty & 0,341 & $* * * *$ & Signifikan \\
Brand Loyalty $\rightarrow$ Brand Equity & 0,529 & $* * * *$ & Signifikan \\
\hline
\end{tabular}

Sumber: Data diolah, 2018

Berdasarkan tabel6dapat dilihat bahwa secara umum variabel perceived quality memiliki pengaruh langsung terhadap variabel brand equitysebesar 0,333 dengan p-value sebesar 0,002. Pengaruh tersebut menunjukkan angka yang signifikan dan dapat diterima, karena p-value kurang dari 0,05. Hasil ini menunjukkan bahwa semakin baik persepsi kulitas yang dimiliki konsumen maka semakin baik pula ekuitas merek yang dihasilkan dan sebaliknya jika persepsi kualitas yang di miliki konsumen akan menjadikan ekuitas merek semakin kecil atau berkurang.

Hasil ini sejalan dengan penelitian yang dilakukan Karupannan et al.(2012) bahwa persepsi kualitas menjadi kontributor utama dalam mendukung ekuitas merek. Kualitas adalah aspek yang penting untuk meningkatkan ekuitas merek. Perusahaan harus memastikan kualitas terbaik terhadap merek mereka untuk membuat ekuitas merek. Kegiatan promosi yang efektif seperti iklan, promosi dari mulut ke mulut, promosi penjualan, citra perusahaan dan sponsorship akan membantu perusahaan dalam membangun persepsi kualitas yang tinggi bagi merek sehingga akan membentuk ekuitas merek yang tinggi.Maya Widjaja dkk. (2007) dalam penelitiannya menyatakan bahwa sebuah merek bila mampu 
memberikan produk dan jasa yang sesuai dengan apa yang diharapkan konsumennya, maka persepsi kualitas yang dimilikinya adalah yang terbaik dan paling positif.

Berdasarkan tabel 6 dapat dilihat bahwa secara umum variabel brand image memiliki pengaruh langsung terhadap variabel brand equitysebesar 0,363 dengan p-value sebesar 0,026. Pengaruh tersebut menunjukkan angka yang signifikan dan dapat diterima, karena $p$-value kurang dari 0,05. Hasil ini menunjukkan bahwa semakin baik citra yang dimiliki konsumen terhadap merek maka akan memberikan nilai ekuitas yang baik pula bagi merek dan sebaliknya jika citra yang dimiliki konsumen terhadap merek tidak baik maka akan menjadikan ekuitas merek menurun.

Hasil ini sejalan dengan penelitian yang dilakukan oleh Jumiati Sasmita dan Norazah Mohd Suki (2014) menunjukkan bahwa variabel brand image berpengaruh positif terhadap brand equity. Ketika produk tersebut memiliki brand image yang positif, konsumen sadar bahwa produk atau merek tersebut memiliki keunikan dibandingkan dengan produk atau merek lain.Penelitian yang dilakukan oleh Muhammad Qasim et al. (2017) menghasilkan bahwa citra merek merupakan penentu utama dari ekuitas merek.

Berdasarkan tabel 6 dapat dilihat bahwa secara umum variabel perceived quality memiliki pengaruh langsung terhadap variabel brand loyalty sebesar 0,341 dengan p-value sebesar 0,000. Pengaruh tersebut menunjukkan angka yang signifikan dan dapat diterima, karena p-value kurang dari 0,05. Hasil ini 
menunjukkan bahwa semakin baik persepsi kualitas yang dilimiki konsumen akan membuat konsumen setia terhadap merek.

Penelitian yang dilakukan oleh Chandrarina pada tahun 2012 menyatakan bahwa semakin baik persepsi kualitas maka semakin tinggi loyalitas merek responden. Perceived quality menghasilkan value ke konsumen dengan menyediakan alasan untuk membeli produk dan pembedaan merek dalam suatu kompetisi merek. Hal ini dapat terjadi karena jika konsumen menerima merek sebagai kualitas superior akan menjadi lebih loyal terhadap merek.Hasil penelitian ini sejalan dengan penelitian yang dilakukan oleh Ireem et al. pada tahun 2012, Hong et al. pada tahun 2012 serta Fanny dan Diah pada tahun 2014.

Berdasarkan tabel 6 dapat dilihat bahwa secara umum variabel brand image memiliki pengaruh langsung terhadap variabel brand loyaltysebesar 0,529 dengan p-value sebesar 0,000. Pengaruh tersebut menunjukkan angka yang signifikan dan dapat diterima, karena $p$-value kurang dari 0,05. Hasil ini menunjukkan bahwa semakin baik citra yang dilimiki konsumen terhadap merek maka akan menjadikan konsumen setia terhadap merek.

Mengacu pada kepuasan dan loyalitas, penting bagi perusahaan untuk menentukan kepuasan pelanggan dalam rangka untuk memeriksa produk atau layanan gambar mereka, kinerja dan apakah pelanggan yang puas mereka bersedia untuk menyarankan produk mereka kepada orang lain selain memiliki maksud untuk pembelian produk atau layanan di masa depan (Rashid et al. 2013). Hasil penelitian ini juga sejalan dengan penelitian yang dilakukan oleh Muhammad 
Rizan dkk pada tahun 2012, Abdullah pada tahun 2015 dan Danny Alexander pada tahun 2014 .

Berdasarkan tabel 6 dapat dilihat bahwa secara umum variabel brand loyalty memiliki pengaruh langsung terhadap variabel brand equitysebesar 0,474dengan p-value sebesar 0,007 . Pengaruh tersebut menunjukkan angka yang signifikan dan dapat diterima, karena p-value kurang dari 0,05. Hasil ini menunjukan bahwa semakin setia konsumen terhadap merek maka akan memberkan nilai ekuitas merek yang tinggi bagi perusahaan.Hasil penelitian ini sejalan dengan penelitian yang dilakukan oleh Hossien et al. pada tahun 2012, Shen Lei dan Luo Chu pada tahun 2015, Tulay et al. pada tahun 2017, Anis pada tahun 2010 dan Selly pada tahun 2012 dimana dalam penelitian tersebut dikatakan bahwa brand loyalty memiliki pengaruh yang positif dan signifikan terhadap brand equity.

Terbukti secara empiris dalam penelitian ini bahwa terbentuknya brand equity sangat dipengaruhi oleh variabel perveived quality, brand image dan brand loyalty. Dapat dilihat dari hasil penelitian seluruh hipotesis memiliki hasil yang positif dan signifikan. Saat persepsi kualitas yang dirasakan konsumen sesuai dengan apa yang diharapkan maka hal tersebut akan menjadi modal besar untuk Samsung Galaxy dalam meningkatkan ekuitas merek mereka karena konsumen mempercayai bahwa kualitas handphone Samsung Galaxy memang baik.

Saat persepsi konsumen telah sesuai dengan harapan mereka maka akan terbentuk citra dari merek tersebut. Citra yang dimiliki sebuah merek akan sangat membantu merek untuk mendapatkan posisi dalam pasar. Dengan citra merek yang baik maka akan meningkatkan ekuitas dari merek tersebut. Samsung dengan 
produk handphone Samsung Galaxy telah berhasil menciptakan citra yang baik dalam benak konsumen. Dengan citra merek yang baik maka ekuitas merek dari handphone Samsung Galaxy akan semakin tinggi dalam pasar dan loyalitas konsumen akan mulai tercipta.

Loyalitas konsumen dapat terjadi saat segala aspek yang menjadi pertimbangan konsumen dapat dipenuhi oleh sebuah merek. Dengan loyalitas tinggi maka akan sangat mendukung merek untuk meningkatkan ekuitas merek mereka.

Beberapa keterbatasan dari penelitian ini adalah ruang lingkup penelitian ini hanya untuk konsumen handphone Samsung Galaxy di kota Denpasar, sehingga penelitian ini tidak dapat digeneralisasi untuk konsumen secara keseluruhan. Untuk penelitian selanjutnya akan lebih baik bila cakupan penelitiannya diperluas agar dapat melihat bagaimana penerapan brand equity pada suatu merek dengan menggunakan variabel lain yang mendukung.

Penelitian ini hanya dilakukan dalam titik waktu tertentu (cross section), sedangkan lingkungan bersifat sangat dinamis sehingga diharapkan penelitian dapat dilakukan kembali di masa mendatang.

\section{SIMPULAN DAN SARAN}

Berdasarkan hasil pembahasan penelitian yang telah dilakukan, maka dapat disimpulkan bahwa secara keseluruhan tiap variabel dalam penelitian ini memiliki hubungan yang signifikan dan positif. Itu artinya setiap varibel saling berkaitan satu sama lain dan saling mendukung. 
Mendapatkan sebuah ekuitas merek yang baik tidak terlepas dari bagaimana konsumen memiliki persepsi atas produk Samsung Galaxy ini. Semakin baik persepsi yang dimiliki konsumen hal tersebut akan memberikan citra merek yang baik. Adanya citra merek yang baik ini akan sangat menguntungkan bagi Samsung terutama dalam hal meluaskan pangsa pasar dengan tujuan menguasai pasar dalam hal ini adalah pasar smartphone di Indonesia. Citra yang baik ini juga akan mendorong kosumen yang telah menggunakan handphone Samsung Galaxy menjadi loyal terhadap merek Samsung Galaxy.

Berdasarkan kesimpulan yang telah dipaparkan, maka saran yang dapat diberikan adalah penting bagi pihak manajemen Samsung untuk terus memperhatikan dan meningkatkan perceived quality, brand image dan brand loyalty konsumen terhadap handphone Samsung Galaxy, karena ketiga variabel tersebut sangat memperngaruhi terbentuknya brand equity bagi perusahaan. Hal yang perlu diperhatikan adalah selalu menjaga kualitas produk agar saat produk dipasarkan tidak terjadi kerusakan yang disebabkan oleh tidak berjalannya sistem handphone dengan baik yang dapat menyebabkan menurunnya brand image konsumen terhadap perusahaan yang akan berpengaruh terhadap brand loyalty dan brand equity konsumen terhadap perusahaan.

Penelitian di masa mendatang perlu mempertimbangkan untuk menggunakan variabel lain yang belum ada dalam penelitian ini, sehingga dapat menyempurnakan pemahaman terhadap faktor-faktor yang mempengaruhi brand equity sehingga dapat memperkaya informasiyang diperoleh.

\section{REFERENSI}


Aaker, David A. (1997). Ekuitas Merek. Edisi Indonesia. Jakarta: Mitra Utama

Abdulla Alhaddad. (2015). A Structual Model of the Relationshio Between Brand Image, Brand Trust and Brand Loyalty. International of Management Research and Review, 5 (1), pp: 137-144

Ahmed, Ishfaq; Shaukat, Muhammad Zeeshan; Nawaz, Muhammad Musarrat; Ahmed, Naveed; Usman, Ahmad. (2011). Determinants of the Satisfaction and Repurchase Intentions of Users of Short Messenger Services (SMAS): A Study in the Telecom Sector of Pakistan. International Journal of Managemen, 28(3), pp : 763-772.

Chahal Hardeep and Madhu Bala. (2010). Significant components of service brand equity in healthcare sector. International Journal of Health Care Quality Assurance, 25 (4), pp : 343-362.

Chandrarina Ike Torananingrum. (2012). Pengaruh Perveived Quality, Brand Affect dan Brand Trust terhadap Brand Extention dengan Brand Loyalty dan Brand Equity sebagai mediator (Studi kasus konsumen Lifebuoy di Solo dan Karanganyar). Tesis Program Pascasarjana pada Program magister manajemen Universitas Sebelas Maret, Surakarta.

Danny Alexander Bastian. (2014). Analisa Pengaruh Citra Merek (Brand Image) dan Kepercayaan Merek (Brand Trust) Terhadap Loyalitas Merek (Brand Loyalty) ADES PT. Ades Alfindo Putra Setia. Jurnal Manajemen Pemasaran Petra, 2 (1), h: 1-9.

Endang Tjahjaningsih dan Maurine Yuliani. (2009). Analisis Kualitas Produk dan Citra Merek dalam Mempengaruhi Keputusan Pembelian dan Dampaknya Terhadap Loyalitas Merek HP Nokia. Telaah Manajemen, 6 (2), h : 104118.

Erfan Severi., Choon Ling, Kweek. (2013). The Mediating Effects of Brand Association, Brand Loyalty, Brand Image and Perceived Quality on Brand Equity. Asian Social Science, 9 (3), pp: 125-137.

Fanny Fibriyanti Salim dan Diah Dharmayanti. (2014). Pengaruh Brand Image dan Perceived Quality Terhadap Kepuasan dan Loyalitas Pelanggan Mobil Toyota di Surabaya. Jurnal Manajemen Pemasaran Petra, 2 (1), h: 1-8.

Hong, Youl Ha and Kang Hee Park. (2012). Effects of perceived quality and satisfaction on brand loyalty in China: The moderating effect of customer orientation. African Journal of Business Management, 6 (22), pp: 67456753. 
Jumiati Sasmita., Norazah Mohd Suki. (2014). Young Consumers Insights on Brand Equity. International Journal of Retail and Distribution Management, 43 (3), pp: 276-292.

Lei, Shen and Chu, Luo. (2015). The Mediating Role of Consumer Satisfaction in the Relationship between Brand Equity and Brand Loyalty based on PLSSEM Model. International Business Research, 8 (2), pp: 62-70.

Mahsa Pishdar., Mohammad Reza Seyyed Hashemi Toloun., Fereshteh Farzianpour and Morteza Rezaeiasl. (2014). Modeling The Effectiveness Of The Corporate Identity Mix In Perceived Quality And CostumerRelated Brand Equity With Interpretive Structural Equations And Micmac Analysis.American Journal of Applied Sciences, 11 (4), pp: 548-557.

Maya Widjaja, Serli Wijaya dan Regina Jokom. (2007). Analisis Penilaian Konsumen Terhadap Ekuitas Merek Coffee Shops Di Surabaya. Jurnal Manajemen Perhotelan, 3 (2), h :89-101.

Muhammad Qasim Shabbir., Ansar Ali Khan and Saba Rasheed Khan. (2017). Brand Loyalty, Brand Image and Brand Equity : The Mediating Role of Brand Awareness. International Journal of Innovation and Applied Studies, 19 (2), pp: 416-423.

Rahyuda, Ketut. (2004). Buku Ajar Metodelogi Penelitian. Denpasar: Fakultas Ekonomi Universitas Udayana.

Rashid Saeed, Rab Nawaz Lodhi, Amna Mehmood, Urooj Ishfaque, Fareha Dustgeer, Amna Sami, Zahid Mahmood and Moeed Ahmad. (2013). Effect of Brand Image on Brand Loyalty and Role of Customer Satisfaction in it. World Applied Sciences Journal, 26 (10), pp: 1364-1370.

Severi, Erfan., and Kwek Choon Ling. (2013). The Mediating Effects of Brand Association, Brand Loyalty, Brand Image and Perceived Quality on Brand Equity,Asian Social Science9(3), pp : 125-137. 